\title{
ANALYSIS OF PRIVATIZATION: DIFFERENT APPROACHES
}

\author{
Manuela Tvaronavičienė ${ }^{1}$, Kristina Kalašinskaitė ${ }^{2}$ \\ Vilnius Gediminas Technical University, Saulètekio al. 11, LT-10223 Vilnius, Lithuania, \\ e-mail: manuela@post.omnitel.net ${ }^{1}, k r i s t i n a . k a l a s i n s k a i t e @ v v . v t u . l t^{2}$
}

Received 0501 2005; accepted 31012005

\begin{abstract}
Presented paper strives to elaborate privatization as one of national economy development tools. Performance of privatized enterprises has been taken into consideration. The authors examine different opinions about privatization process and its efficiency taking a close look at the researches that have been already made. Analysis has been targeted to implications' diversity due to foresee those in transition countries. Governance issues in case of privatization of monopolistic enterprises have been discussed.
\end{abstract}

Keywords: privatization, restructuring of economy, monopoly, transition economies, economic policy.

\section{Introduction}

The political and economic policy of privatization is defined as the sale of state enterprises by government. Since its introduction by Britain's Thatcher government in the 1980s, the privatization's programs have spread in the developed and developing countries. The subjects of privatization often occur to be the monopolistic companies, which are significant for development of national economy by themselfs. Therefore privatization as tool of economy restructuring can play significant role in transition economies especially. Economists unanimously agree that privatization is to make a different impact on economies in the different stages of development. Very important question arises how implement successfully appropriate privatization program. An analysis of the literature on privatization and the findings of different authors have led to distinguish and discuss key aspects of privatization as tool of economy policy.

\section{Importance of privatization: the case for and against privatization}

Privatization means the transfer of assets hitherto owned by the state into private hands. The broader interpretation covers the property relations in the economy as a whole, so that privatization of the economy must be understood to mean that the share of the private sector grows until it ultimately becomes the dominant economic sector. An extension of broad definition provides more insight in the process of privatization. Beside the selling or leasing of public property, the term implies the abandonment of any government control over all units of the economy, as well as the state monopoly in certain sectors [1].

Privatization process has begun in Great Britain and now, in the past two decades, it is in use worldwide. The depression, World War II, and the final break up of colonial empires pushed government into a more active role, including ownership of production and provision of all types of goods and services, in much of the world. In Western Europe, governments debated how deeply involved the national government should be in regulating the national economy and which industrial sectors should be reserved exclusively for state ownership. Until Margaret Thatcher's conservative government came to power in Great Britain in 1979, the answer to this debate in the United Kingdom and elsewhere was that the government 
should at least own the telecommunication and postal service, electric and gas utilities, and most forms of non-road transportation (especially airlines and railroads) [2].

Important notice is, that state ownership may also serve as means of promoting the public interest when entire businesses are about to collapse. The state has sometimes intervened to prevent liquidation, as in 1970 when the Conservative government decided to rescue Rolls-Royce rather than see the company liquidated [4].

Increasingly privatizations have become much more complex, often being used to restructure industries be breaking up monopolies and establishing market-based relationships between the new companies [4]. This is a privatization policy whereby services carried out by the public sector are franchised to private contractors.

Theoretical discussion focuses the arguments for and against privatizations:

\begin{tabular}{|l|l|}
\hline The case for privatization & $\begin{array}{l}\text { The case against } \\
\text { privatization }\end{array}$ \\
\hline $\begin{array}{l}\text { Increased competition in } \\
\text { production in product and } \\
\text { service markets }\end{array}$ & $\begin{array}{l}\text { Natural monopolies } \\
\text { versus private } \\
\text { monopolies }\end{array}$ \\
\hline $\begin{array}{l}\text { Increased discipline of } \\
\text { capital markets }\end{array}$ & Short-termism \\
\hline $\begin{array}{l}\text { Reduction in government } \\
\text { borrowing }\end{array}$ & $\begin{array}{l}\text { Economies of scale and } \\
\text { scope may lost }\end{array}$ \\
\hline $\begin{array}{l}\text { Reduction in government } \\
\text { controls }\end{array}$ & $\begin{array}{l}\text { Difficulties in } \\
\text { introducing competition }\end{array}$ \\
\hline
\end{tabular}

These arguments are discussed in the other chapter of paper below.

\subsection{The case for privatization}

By the early 1980s privatization was also supported by adherents of "supply side" economics with its emphasis on free markets. Privatization would expose industries to market forces which would benefit consumers by giving them choice, and also lower prices as a result of efficiency gains within the privatized companies.

The breaking of a state monopoly (e.g. Mercury competing with British Telecom (BT)) would, in this view, enable consumers to choose whichever company produced the service they preferred. That company would then generate more profit and expand in response to consumer demand, whilst competitive pressure would be put on the company losing business to improve its service or go into liquidation. BT's progressive reductions in phone charges and internet access charges in recent years have clearly been at least partly in response to competition. The pressure to meet consumer requirements should also improve internal efficiency ( $\mathrm{X}$ efficiency) as changes can be justified to workers and managers by the need to respond to the market. The old public corporations had increasingly been seen as producers led, serving the interests of management and workers rather than those of consumers and shareholders (in this case taxpayers). Privatization introduces market pressures which help to stimulate a change of organizational culture.

Trade union can be expected to discover that previous customs and work practices agreed when in the public sector are now challenged by privatization, as the stance taken by management changes from when it was a nationalized industry, and thereby raises corporate efficiency. Similarly competition in the product market will force moderation in wage demands and increased attention to manning levels, again raising efficiency. Privatization contributes in these various ways to the creation of flexibility in labor markets, higher productivity and reduced unit labor costs.

The stock market provides a further market test for privatized companies. Poor performance in meeting consumer preference or in utilizing assets should result in a share price which underperforms the rest of the market and undervalues the company's assets, ultimately leaving it vulnerable to takeover by a company able to make better use of the assets. Supporters of privatization place more faith in these market forces than in the monitoring activities of Departments of State and parliamentary Committees.

The activities of state-owned organizations are constrained by their relationship with the government. They lack financial freedom to raise investment capital externally because the government is concerned about restraining the growth of public expenditure. Privatization is then seen as increasing the prospects for raising investment capital, thereby increasing efficiency and lowering prices.

A further limitation on nationalized industries is the political near-impossibility of diversification. In many cases this would be the sensible corporate response to poor market prospects but it is not an option likely to be open to a nationalized concern. Since privatization, however, companies have been able to exploit freely market opportunities. So, for example, most of the regional electricity companies have become suppliers of gas as well as electricity. 
The globalization of economic activity also, in this respect, leaves nationalized industries at a distinct disadvantage. For example, no private oil company would follow the nationalized British Coal in confining its activities to one country where it happened to have reserves. This international perspective is an important reason why the Post office management has seen privatization as the only (option) which offers us the freedom to fight off foreign competition. In The postal services, increased, and from further liberalization of other national postal services expected within the European Single Market. The difficulties of an international strategy for nationalized industries are shown by the failure of the attempted Renault-Volvo merger in 1993. The then nationalized status of Renault contributed substantially to Swedish (Volvo) shareholder opposition to the merger.

Privatization, then, is seen by its supporters as a means of greatly improving economic performance.

\subsection{The case against privatization}

An essential aspect to the case for privatization is the creation of competitive market conditions. However, some state-owned industries have always faced stiff competition in their markets (for example, Post Office Parcelforce from DHL), so that privatization of these industries might be considered irrelevant on the basis of this competitive market conditions argument.

The government also face a dilemma as regards creating competitive market conditions when privatizing public utilities which are monopolies; namely for the Treasury. Breaking up state monopolies in order to increase competition reduces the market value of the share offer; monopolies are likely to be worth more as share offers because uncertainty for investors. Critics would say that the government has allowed the creation of competition to be secondary to creating attractive share issues which sell easily. The result has been the transfer of public utility monopolies intact to the private sector, creating instead private sector monopolies.

Nevertheless, competitive pressures are being applied to some of the previously public utility monopolies in their newly privatized form. For example, at the time of privatization, British Gas appeared to be a classic natural monopoly. Since then consistent pressure from the regulatory authorities has created competitive market conditions in the supply of gas to industry, to such an extent that by 2000 the British Gas share of the industrial market was below $30 \%$ and competitive supply had been extended to the domestic market for gas across the whole country. As regards BT, from the very beginning its monopoly position was challenged by Mercury. However opportunities for new entrants created by rapid technical change have been even more significant in eroding the market dominance of BT. Cable TV companies can now additional many large organizations have created their own phone cable systems; additionally many large organizations have created their own phone networks and the Internet and digital TV are creating still further opportunities for communication.

The technical and regulatory change in the telecommunication and gas industries have benefited consumers but should not be confused with the issue of the desirability of privatization. Consumers might imagine that this desirable outcome could have been achieved under public ownership. If so, critics might then argue that consumers could have experienced still greater benefit from technical innovation because, under privatization, tax regulatory regimes have allowed excessive levels of profit, to the benefit of shareholders and executives rather than consumers.

The extension of share ownership does not in itself attract much criticism. The issues which have provoked criticism include the pricing and the marketing of the shares. It is argued of both privately negotiated deals and the public share offers.

In most cases public share offers have been heavily over-subscribed and large percentage profits have been made by successful applicants. Underpriced issues have cost the Treasury substantial revenues and have also conditioned a new class of small shareholders to expect quick, risk-free capital gains. These expectations were encouraged by barrages of skilful advertising. Not surprisingly many of then new shareholders cashed in their windfall gains by selling their shares. As a result share ownership in the new companies quickly became more concentrated.

The discipline of the capital markets may prove a very mixed blessing for some of the privatized companies if they become subject to the City's alleged short termism. The large investment fund managers are often criticized for taking a short-term view of prospects. This would be particularly inappropriate for the public utilities where both the gestation period for investment and pay-back period tend to be lengthy. The freedom with which ownership of assets changes hands on the stock market is not always in the public interest.

The flow of funds into privatization offers has been diverted from other uses. It is reasonable to suppose that applicants for shares are using their savings rather 
than reducing their consumption. Large sums of money leave the building societies during privatizations, and other financial institutional are also deprived of funds. This raises the possibility that what is merely a destructing and change of ownership of state industry may be reducing the availability of funds for other organizations which would use them for real capital investment. The effects of privatization issues on the financial markets are much the same as the effects of government borrowing, raising the same possibilities of 'crowding out'.

A final criticism of privatization is a moral one that the public are being sold shares which, as taxpayers, they already collectively own. The purchases of the shares benefit from the dividends paid by the new profit seeking enterprises, at the expense of taxpayers as a group. Those taxpayers, who do not buy the shares, perhaps because they have spare cash, are effectively dispossessed.

\section{Effectiveness of privatization: review of findings research}

Review of literature verifies that privately owned firms are more efficient and more profitable than comparable state-owned firms. Limited empirical evidence, especially from China suggests that non-privatizing reform measures, such as price deregulation, market liberalization, and increased use of incentives, can improve the efficiency of SOEs. Nevertheless, it also seems likely that these reforms would be even more effective if coupled with privatization [2].

The effectiveness of the change of ownership depends on the market structure: the more competitive the structure of the market, the more effective the privatization. Second, the corporate governance system--which we define broadly as the set of mechanisms controlling the managers' decisionsassociated with privatization is usually thought to perform better than the corporate governance system of the state-owned enterprises [5].

Review of articles by Djankov and Murrell (2000a,b) and a macroeconomic study by Jeffrey Sachs, Clifford Zinnes, and Yair Eilat (2000) examine the effects of privatization in transition economies. Djankov and Murrell review the empirical results of studies of privatization in transition economies and attempt to synthesize the results across the studies. They conclude that the evidence show the following: in most countries, privately owned firms perform better than state-owned firms, usually significantly better statistically; there is little evidence that privatization has hurt firms' performance even in Russia and other Commonwealth of Independent States (CIS) countries. Much better outcomes occur when the new owners are concentrated. Privatization itself has had a larger positive impact in non-CIS countries, eastern and central Europe, and the Baltic States than in the CIS countries. They interpret the last result to be caused by institutional factors, including the choice of privatization method. They suggest the best empirical proxy for how well the institutions performed was the length of time the country had spent under communism-the shorter the time the better the performance of the institutions.

Empirically, at a macro level, Sachs, Zinnes, and Eilat (2000) examine the relationship between privatization, institutional reforms, and overall economic performance (measured by change in GDP from before transition, foreign direct investment, and exports) in transition economies. They find that change in ownership is not enough to improve macroeconomic performance. The gains from privatization come from change in ownership combined with other reforms such as institutions to address incentive and contracting issues, hardened budget constraints, removal of barriers to entry, and an effective legal and regulatory framework. While this is a macroeconomic study, the changes they report must come from the operations of individual firms.

Their reading of the evidence from transition economies is very similar. Privatization improves performance but various factors impact the success of the privatization. Most important is that allowing incumbent managers to gain control of privatized firms, through whatever means, will yield disappointing results. Whenever possible, firms should be privatized, for cash, in as transparent a method as possible, and through an auction or sale process that is open to the broadest possible cross-section of potential buyers (including foreigners) [2].

D'Souza et al. (2000), finds stronger efficiency gains for firms in developing countries, in regulated industries, in firms that restructure operations after privatization, and in countries providing greater amounts of shareholder protection.

They now turn to an examination of research findings about privatization's impact in transition economies. Privatization is both more difficult and more allencompassing in these countries than it is in either industrialized or non-transition developing countries. This is because in transition economies, privatization is only part of the massive changes in the economy as countries move from communism to more market 
oriented methods of allocating resources and organizing production [2].

Privatization in transition countries has often been partial, with the state retaining a non-controlling ownership share in privatized assets. This paper reviews briefly the empirical evidence and then analyzes the justifications that have been put forward for adopting partial privatization. These are related to the objectives of economic efficiency and the generation of government revenue, as well as to political motivations. The issues covered are the stockflow problem, risk - sharing and restructuring, informational considerations, the role of market structure, bargaining, foreign investment and the irreversibility of reform. The paper ends with some suggestions for further research [6].

Through a retrospective analysis of Mexico's oil history, this work examines the privatization processes that occurred in the petrochemical sector, from the abolishment of the government's monopoly, Petróleos Mexicanos (PEMEX) during the 1980s, until the restructuring and open liberalization in the early 1990s, focusing on the areas incorporated to production processes, particularly along the Gulf coast. As a result of the industrial policies and regional development strategies promoted by the government from the sixties, oriented towards strengthening production in areas with the highest potential, attractive business investment areas were developed. These included southern Tamaulipas, a strategic region where a number of industrial factors facilitated access to raw materials at competitive prices, as well as their processing and distribution to local and international markets, all of these within a single location. The strategic nature of the petrochemical location and production have made southern Tamaulipas a key factor for the territorial shaping and industrial development linked to the behavior of transnational companies that, seeking comparative advantages, have relocated parts of their production capacity in this region [7].

They interpret privatization in light of corporate governance theory. After replicating some traditional tests, they test their new model on a sample of privatized French firms. They cannot confirm for French privatizations the positive effect on overall static and dynamic efficiency of the firm traditionally attributed to privatizations. In addition, they find that whatever positive value accrues from privatization is affected by the contextual, organizational, governance, and strategic variables that influence the privatization process.
At first, the superficial examination of the principal indicators, based on means and medians, show substantial change. On average, the privatized companies show an increase in their economic and financial profitability and their productivity [5].

Intensive privatization in Lithuania stood for the main form of foreign investment and could be identified as one of the most important channels of FDI inflows. Basing on poll of the biggest firms of foreign capital performed by Institute of Free Market Economy (the biggest investors' analysis of FDI source has been done (Figure).

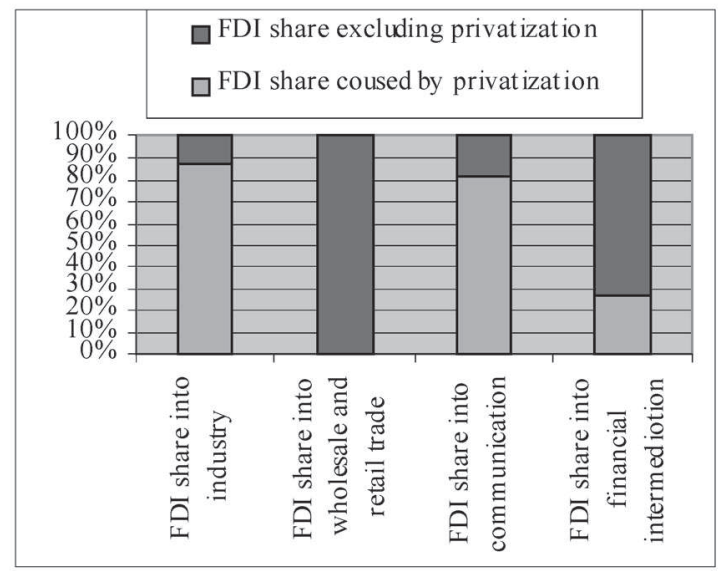

FDI distinguished as green field investments and privatization means

Privatization of such public monopoly as Lithuanian Telecom (communication) and Mazeikiu nafta (industry) have conditioned the most significant inflows of foreign capital.

\section{Regulation of privatized companies}

Bernardo Bertolotti and Domenico Siniscalso in their book "The Problems of Privatization: An International Analysis" usefully record and analyze privatization between 1977 and 2001. The authors find a major slowdown after 1999 (1997 in Latin America), not because the stock of state-owned enterprises was exhausted but easy ones had been done and doubts began to be raised about the alleged benefits of privatization, which often seemed slow to materialize. The authors also find a general reluctance by governments to let go of their erstwhile charges, so many 'privatized' enterprises are still subject to governmental control through one channel or another. Perhaps for this reason, the full expected gains have not been realized [3].

The privatization of public utility companies with 'natural' monopolies creates the possibility that the 
companies might abuse their monopoly power.

Regulators have two fundamental objectives. Firstly, they attempt the constraints and stimuli which companies in competitive markets must bear in mind what their competitors are doing when setting their prices and are under competitive pressure to improve their service to consumers in order to gain market share. Regulation can simulate the effects of a competitive market by setting price caps and performance standards. Secondly, regulators have the longer term objective of encouraging actual competition by easing the entry of new producers and by preventing privatized monopoly power maintaining barriers to entry. An ideal is the creation of markets sufficiently competition to make regulation unnecessary.

Regulators have an unenviable role as they try to create constrains and stimuli of a competitive market. Essentially they are arbitrating between the interest of consumers and producers. Other things being equal, attempt by regulators to achieve improvements in service levels will cause inelastic in cost and so lower profits, whilst price caps on services with price inelastic demand will also reduce profits by preventing the regulated industries raising prices and therefore revenue. Lower profits, and the expectation of lower profits, have immediate implications for dividend distributions to shareholders and so for share prices. At this point other things are unlikely to remain equal. The privatized company subject to a price cap may well look for ways of lowering costs to allow profits to be at least maintained, or perhaps raised. In most organizations there are economies to be gained by reducing staffing levels and the utility companies have dramatically reduced their numbers of employees. Investment in new technology may also enable unit costs to be lowered so that profits are greater than they otherwise would have been.

In deciding on a price cap the regulator has in mind some 'statisfactory' rate of profit on the value of assets employed. A key issue is then the valuation of the assets. If the basis of valuation is historical, using the market value at privatization plus an estimate of investment since that date, then the company will face a stricter price cap than if current market valuations are used for assets. This is because historic valuations will usually be much smaller than the current valuations and so will justify much smaller total profits and therefore lower prices to achieve that profit.

It may be over-simplistic to assume that privatized companies will invariably respond to a price cap by cutting costs as much as possible in order to maximize profits over the medium term period of the price cap. The planning period in public utilities is likely to be much longer than the four or five years of a regulator's price review period. If a company meets its price cap and service requirements by making excessively large efficiency savings so that its profits and share price grow quicker than the average for large companies, then there will be great public probably include avoiding the long term regulatory regime becoming too 'tight'. At the same time the regulator may depend on the company for a great deal of the information needed for task of regulation. So there is the possibility of the regulators independence being compromised, which has been called 'capture' of the regulator. Clearly the relationship between regulator and regulated company is complex, so that simple predictions of action and reaction are difficult to make.

The performance of both state owned and privatized industry is difficult to evaluate. It has not been convincingly demonstrated that the form of ownership of an organization is the most important influence on its performance. Of much greater importance would seem to be the degree of competition and the effectiveness of regulatory bodies. Certainly greater powers are being given to many of the regulators of the previously nationalized industries in an attempt to prevent the abuse of monopoly power by the now privatized utilities. Regulators may impose price-caps and use other devices to prevent consumers being 'exploited' in monopoly-type situations. They also seek to open markets to additional competition by encouraging new entrants. Nevertheless there is also a counter-movement which seeks to remove regulations where these are thought to operate against the public interest. Such attempts at deregulation are widespread, though it should not be forgotten that the reason many regulations exist is to protect consumers from the adverse consequences of various types of 'market failure'.

\section{Conclusions}

1. Privatization is the transfer of assets or economic activity from the public sector to the private sector.

2 . The case for privatization includes allegedly greater productive efficiency (lower cost) via the introduction of market pressures. These are seen as creating more flexibility in labor markets, higher productivity and reduced unit labor costs. More widespread share ownership, easier access to investment capital, greater scope for diversification, and the absence of civil service oversight, are often quoted as advantages of privatization. 
3. The case against privatization includes suggestions that state monopolies have often merely been replaced by private monopolies, with little benefit to consumers. The loss of scale economies (e.g. 'natural monopolies'), the inability to deal effectively with externalities, undervaluation of state assets, the subsequent concentration of share ownership, 'shorttermism' of the city are often quoted as disadvantages of privatization.

4. The effectiveness of the change of ownership depends on the market structure: the more competitive the structure of the market, the more effective the privatization.

5. Privatization is both more difficult and more allencompassing in these countries than it is in either industrialized or non-transition developing countries. This is because in transition economies, privatization is only part of the massive changes in the economy as countries move from communism to more market oriented methods of allocating resources and organizing production.

6. Regulators have been appointed for a number of public utilities in an attempt to simulate the effects of competition (e.g. limits to price increases and to profits), when there is little competition in reality.

7. Other regulators are widely used in all economic sectors in order to protect consumers from 'market failure' and to prevent such failures actually occurring.

8 . There is considerable momentum behind removing regulations (i.e. deregulation) where this can be shown to be in the 'public interest'. However, evaluating the welfare change from deregulation is a complex exercise.

\section{References}

1. Aristidis Bitzenis. What was behind the delay in the Bulgarian privatization process? Emerging Markets Finance Trade, Vol 39, No 5, SEmtember-october 2003, p. $58-82$.

2. Megginson, W. L., Nash, R. C. and Van Randenborgh, M., 1994. The financial and operating performance of newly privatized firms: an international empirical analysis. Journal of Finance, 59, p. 403-452.

3. Bernardo Bortolotti, Domenico Siniscalco. The problem of Privatization: An International Analysis. New York: Oxford University Press, 2004. 200 p.

4. Alan Griffiths, Stuart Wall. Aplied economics.

5. Hervé Alexandre and Gerard Charreaux. Efficiency of French privatizations: a dynamic vision. Université de Bourgogne, Iae, Pōle d'économie et de gestion 2, Boulevard Gabriel, BP 26611, 21066, Dijon Cedex, France Received 4 May 2001; Revised 16 May 2002; accepted 12 July 2002. Available online 8 October 2002.

6. James Maw. Partial privatization in transition economies. Economic Systems, Volume 26, Issue 3, September 2002, p. 271-282.

7. Norma Martínez Laguna. Oil policies and privatization strategies in Mexico: implications for the petrochemical sector and its production spaces. Institute of Geography, National University of Mexico (UNAM), Circuito Exterior, Ciudad Universitaria, Delegación Coyoacán, C. P. 04510, Mexico Available online 9 August 2003. 